\title{
総義歯装着者の咀嚼機能評価の再検討
}

\section{Revaluation of masticatory function in denture wearers}

\section{○日塔睦雄，竞藤義樹，児玉厚三，虫本栄子，田中久敏}

\author{
Mutsuo Nitto, Yoshiki Endo, Kozo Kodama, \\ Eiko Mushimoto and Hisatoshi Tanaka
}

\section{岩手医科大学歯学部歯科補釉学第一請座 \\ Dept. of Removable Prosthodontics, Iwate Medical Univ., School of Dentistry}

\section{I. 緒言}

咀噜運動の調節には，上位中枢からの運動司 令情報と㮔々の末梢効果器からのfeedback情報 など多数の情報が関与して扰り。食物の形状 硬度に応した咀嘶リスムと咀罚力を発現してい る.との末梢に扰ける感賞情報としては歯根膜

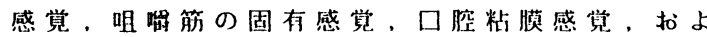
び确関節感覚などがあげられるが、なかでも料 根膜感賞はきわめて重要な役割を演していると とが多くの研究い（2儿より明らかとされている.

Pleshら は，上位中枢のハ夕ーン発生器で 形成された出力信号には，末梢からの感賞情報 により变化を受けにくい部分と变化を受けやす い部分があり，との際歯根膜の機械受容器から の咀筋に対する positive feedback 强く関与していると考察している。また，山田 らへのウサギを用いた研究によれば，咀謝リス 厶すなわち咀嘶周期時問を変動させる要因は主 として開口相時間の変動であり，閉口相時間は 菌根膜なとの末梢感覚受容器からのfeedbackに より一定になるように制御されていると推察し ている。しかしながら，菌根膜感覚をすへて䟚

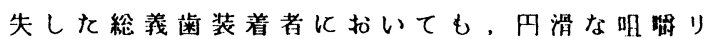
ス厶を調節しているととが知られて扰り，とく に義歯の床下粘膜さらには骨膜などの感賞受容 器が代償的にはたらいているものと孝えられて (る5, B).

演者らは，従来から歯根膜を有しない総義菊 装着者の咀唧運動機能を評価する密観的ハラメ一夕を得るととを目的として，正常有歯哾者及ひ 総義㐘装着者に扰ける末梢feedback（歯根膜感

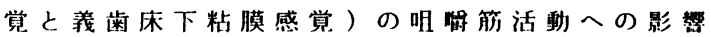
をはしめとする，咀㨐速動についての条統的な 检索を行ってきたさ〜い。すなわち，硬さの異な る被験食品を用いて末梢からの感賞入力を变え た条件下での明運動について解析した結果， 総莪菌装着者の咀㽞運動の時間的要素は硬性食 品で延長し。乙の咀唃䧓期時間の延長の变動因 子は開口相洔間とともに咬合相時闑の著明な延 長に特徵ずけられた。そとで本研究では，歯根 膜と粘膜のfeedbackの)相違に着目し，㐘根膜感 覚と粘膜感覚がそれぞれ上㹲と下頂に别々に存

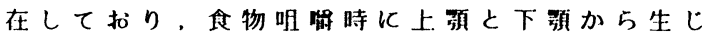
る感覚情報が異なるととが予想される片影義歯 装着者》を被験者として加え，硬さの異なる被 䮖食品を用いて末梢に扰ける感喾受容器の相趡 が咀唧リスムの調節機序に及ほす影辢について，

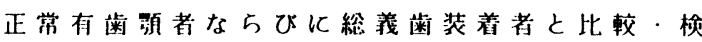
討を行った。

\section{II. 研究方法}

1。被験者打よび被験食品

被験者は臨床的に矛後良好と判定された総義 歯裝着者 5 名（Ｇ１），上歌片弱義菌装着者 6

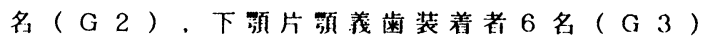
扣よひ正常有歯硕者15名（G4）とした（図1）.

被娩食品は軟性弾性食品の力マボ（15 × 15 $\times 15 \mathrm{~mm})$ ならひ化硬性破挽性食品のビーナッッ $(3.0 \mathrm{~g})$ を用い，テンタ厶な顺序で猊慣性咀謝 側に扣いて㫮下まで朋潞させた。 


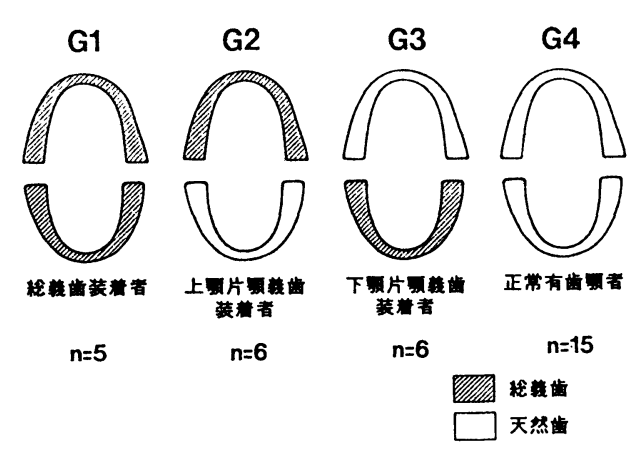

目1本研究の被医者

2.テータの記録ならひ儿分析方法

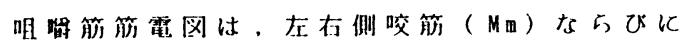
側顽筋媵部（Tp）の4筋から表面電㥛にて双做 莲出し, Sirognathograph飞よる下顼切蒾点部 の動経とともに同時記録を行った。テータは叫 棌開始後 5 ストロ一ク目からの10ストロークを

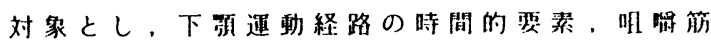
筋電图の時間的要素ならひと程分霄位について 計测を行った。テータの分析は分散分析法によ り, 主変動区子として被験者群ならび被験食 品を設定し、テータの变動に及ほす主効果なら ひとその交互作用效果について縄部学的に検討 を行った.

\section{III . 結果}

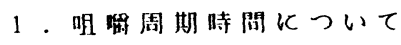

咀程周期時閉の計测結果は（図2），G1 が $643.7 \mathrm{msec}, \mathrm{G} 2$ かi $555.9 \mathrm{msec}$, G 3 が $621.6 \mathrm{msec}$. G 4 が $576.6 \mathrm{msec}$ なり。群間飞有意差は認め られなかった。一方, 被験食品ではカマボコ朋 物で571.5四ecであるのに対し， ヒヒーナッッ

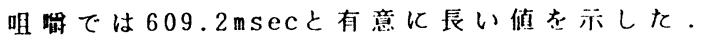
また，群と被験食品との交互作用効果ではG 1

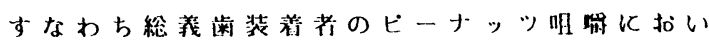
て有意に長い傎を示したものの，それ以外には 差が認められなかった。

\section{2. 開口相時間について}

開口相時間の計测結果は（図 3 ），G 1 が 20 $1.8 \mathrm{msec}, \mathrm{G} 2$ が $161.9 \mathrm{msec}, \mathrm{G} 3$ が $161.7 \mathrm{msec}$.

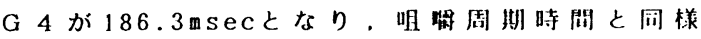
に絰義歯装着者でもっとも長い做を示したが有
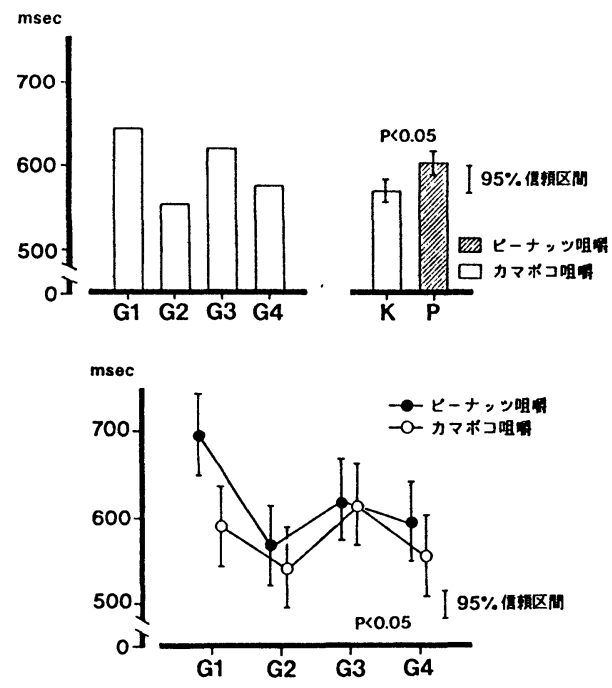

凶2咀嘲周時間の計测结果

上段左：群間の比較

上段右：被倹食品間の比較

下段；群と被験食品との交互作用効果

意差は認められなかった。被駼食品閒をみると，

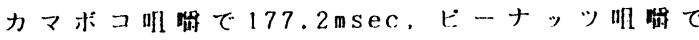
181.1msecとほ同し值を示し，有意差は認め られなかった。てれに对して。群と被験食品と の交互作用效果では，G1すなわち総義歯装馐 者のビ一ナッッ叫喼で不意な延辰を示し，他の

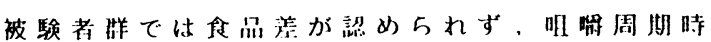
閏と似たような結果となった。

3.閉口相時閶について

閉口相時間の部测結果は（图4）、G1か１9 $5.6 \mathrm{msec}, \mathrm{G} 2$ かi $187.7 \mathrm{msec}, \mathrm{G} 3$ が $216.7 \mathrm{msec}$.

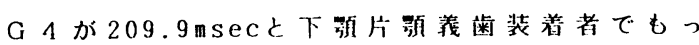
とも長い值を示したか，存意着山望められなかつ

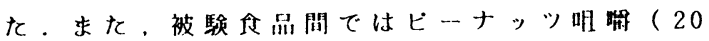
$9.8 \mathrm{msec}$ ) で挔い低を示したものの，カマボユ

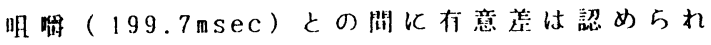
なかった。加えて，群と被験食品との交互作用 効果に扰いても有意差は認められず，䦥口相時 閏では分散分析の結果から，いずれにも有意部 が認められなかった。

4. 咬合相時開について

咬合相時間の㖕测結果は（四５）、G1 が 24 

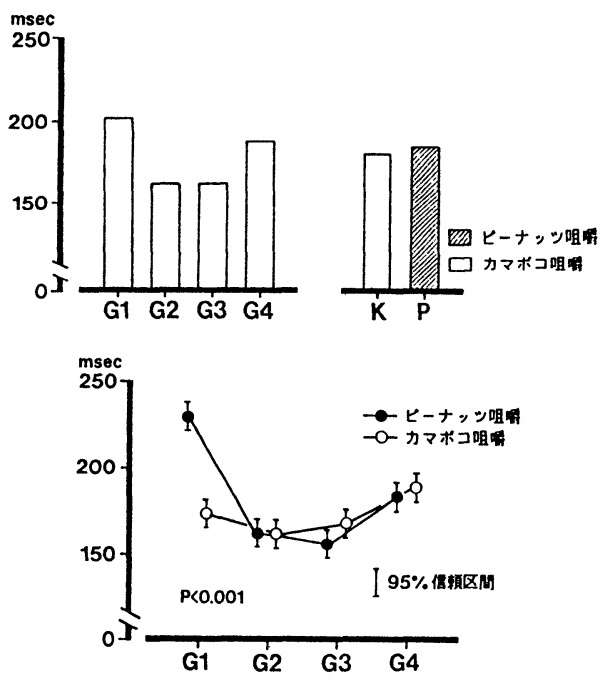

困3開口相時間の計测結果

上段左；群間の比較

上段右; 被験食品間の比較

下段：群と被験食品との交互作用効果
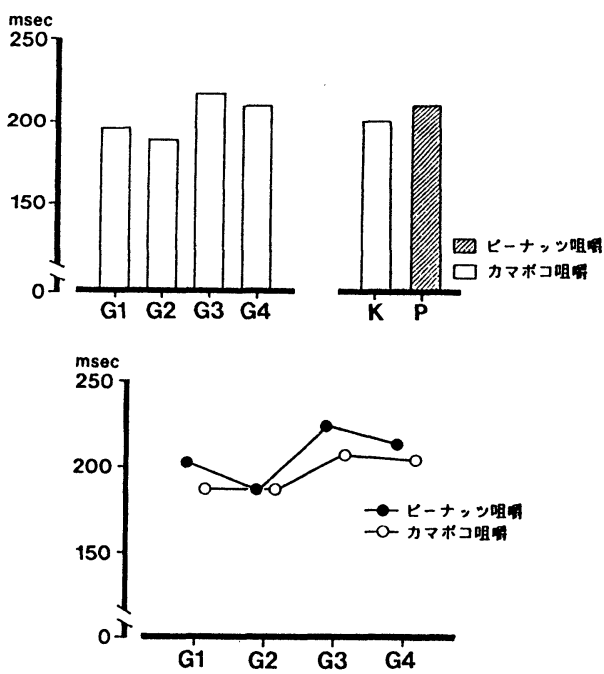

困4閒口相時間の計测䊅果 上段左：群間の比较 上段右：被食品間の比较

下段：群と被験食品との交互作用効果
$6.7 \mathrm{msec}, \mathrm{G} 2$ か $206.3 \mathrm{msec}, \mathrm{G} 3$ が $243.2 \mathrm{msec}$, G 4 が $180.8 \mathrm{msec}$ なり，G1と G 3 で長く有 意差が認められた。また，被験食品開でもビ二

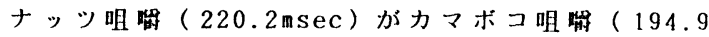
msec）に比較して有意に延長するのが喼められ た。一方, 群と被験食品との交互作用効果では

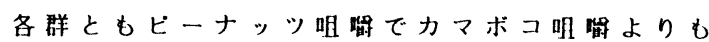
延長するものの，有意差は認められなかった。

5. 咬合相比について

咬合相時間が咀踭周期時間飞占める割合を求 めた咬合相比の結果は（四6），G1 か38.4\%， G 2 か $36.9 \%$, G 3 が $36.9 \%$ ，G 4 か $31.2 \%$ と 正常有歯碩者のG4亿比较して義菌装着者の 3 群で有意に大きな值を示しが，被駼食品閒には 有意差は認められなかった（カマボコ咀踭 33.8 \%，ビーナッツ咀唃 $35.1 \%$ ）。屯た。群と被験 食品の交互作用效果をみると、G 3 では力マボ コ咀舫で大きい值を示したのに対し、G4では ビーナッッ咀謟で大きくなるなど，群間で異な る傾向を示し有意差が認められた。

6.篮放電あたりの樍分電位について

㑬側咬筋に扰け了筋放電あたりの棈分電位の
結果は（図7），G1 が $15.8 \mu \mathrm{Vsec}, \mathrm{G} 2$ が 28 . $4 \mu \mathrm{Vsec}, \mathrm{G} 3$ が $16.0 \mu \mathrm{Vsec}, \mathrm{G} 4$ が $29.2 \mu \mathrm{Vsec}$

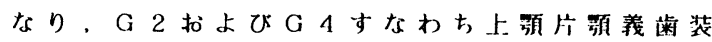
着者之洰常有㐘硕考心打ける筋活動量は G 1 と G 3 よりも标意飞大きな值を示した。机。被

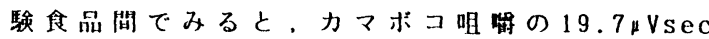

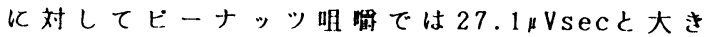
な值を示し有意差が認められた。加えて，群と 被験食品との交互作用効果でも有意差か認めら れ，いずれの群に托いてもビ一ナッッ朋嘶で大

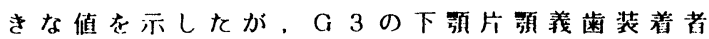
ではその差か小さかった。

$$
\text { N. 考察 }
$$

周期時問の变動は咀程リスムの指標と考えら れるが, 被験食品の硬さによる各被験考群の咀

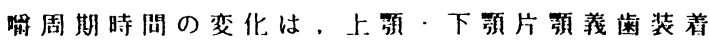
者扰よひ正常有歯额考の3群で食品による变化 が少なかったのに对し、総義藏装着者ではカマ ボコ咀棌に比較してヒーナッッ咀䁌で有意に延 長して扰り食品差か大きく現れた。との結果は， 咀㨐りスムを円滑に制御していくうえでの歯根 膜感覚の重要性を再確認させるものであり，菌 

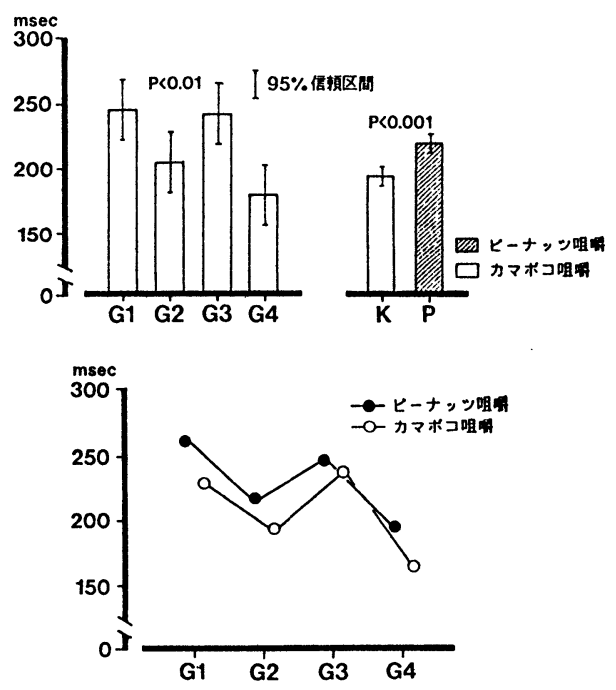

因 5 咬合相時間の計测桔果

上段左；群間の比较

上段右：被騙食品間の比較

下段：群と被駼食品との交互作用効果
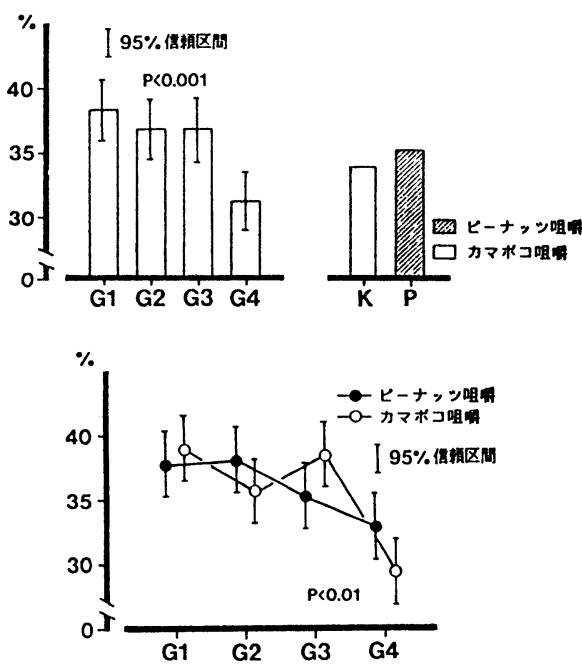

目6 咬合相比

上段左；群間の比較

上段右：被験食品間の比较

下段；群と被駺食品との交互作用効果

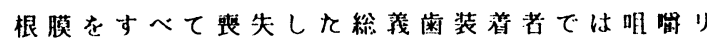

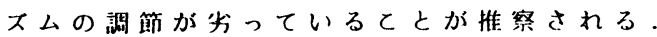

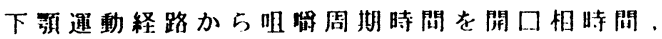
閉口相時問扰よひ咬合相時問飞分割し，周期洔

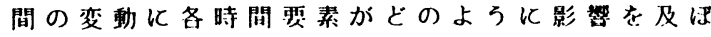

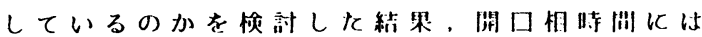
群と被験食品との交互作用効果に。声咬合相 時間には群間拉よひ群と被験食品との交互作用 效果にそれぞれ有意差が認められた。とれに对 して，閒口相時閪は各被験者群とも食品飞よる 变化は少なく、群問扰よひ被験食品開いすれに も有意差は認められなかった，咬合相時間が咀 周期時間に占める割合を\%で求めた咬合相比 は、群問扰よび群と被験食品との交互作用効果 《有意差を認め，正常有歯颜者では他の3群つ まり義歯装着者群に比較して著しく小さく，被 験食品による影響をみると総莪㐘装着者に扰い て食品美は小さかった。てれらの結果はPlesh

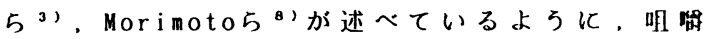
運動のなかでも閉口相時間は安定しておう，開 口相時問と咬合相時閒が延長するととによって 咀题周期時間が延長するという結果と一致し。 また，との倾向は硬性食品でより漖明になるこ とが明らかとなった。したかっでたの閉口
通動は末梢の感筧受答器からの求心性情報によ る影鹤か少なく，上位中枢のハターンジェネレ一 タ一により想则的な速野として制御されている ことが推测された。一方，開口相時閆およる゙咬

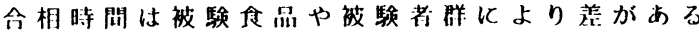

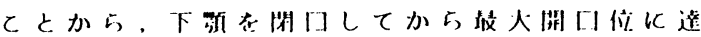
するまでの連動過程は末梢からのsensory inputs により影整を受け，その通動りスくが絶えずコ ントロールされているととが推澌された。さら

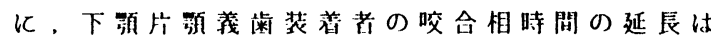

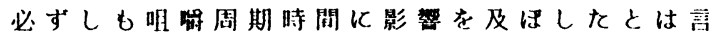
えず，咬合相比に扰いて正常有菌确者か有意心 小さく，他の 3 群闌飞美が認められなかったと

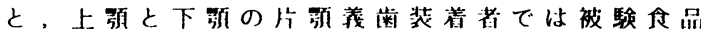
による差が逆のバターンを示したととなどから。 咀调周期時闑の变動因子として歯根膜感賞また は口腔粘膜感覚の関与も否定できないと考えら れた.

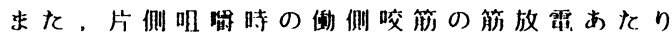

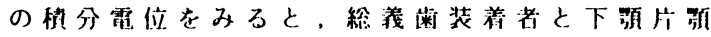

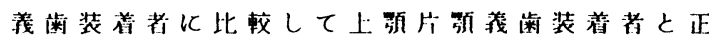
常布藏硕者では有意飞增大していた。つまり。

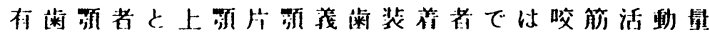
は大きくて咬合相时閒か短いのに対して，総我 

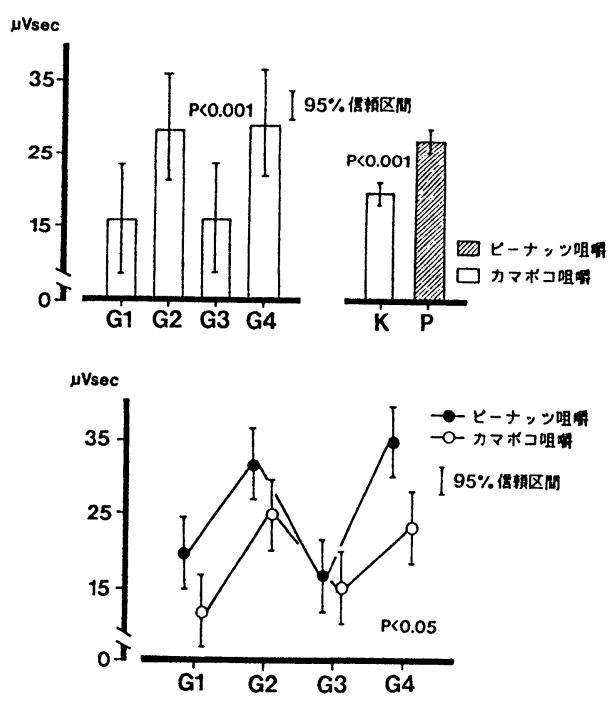

目 7 筋放電あたりの積分電位の計测結果 上段左：群間の比較 上段右；被駼食品間の比較

下段：群と被験食品との交互作用効果

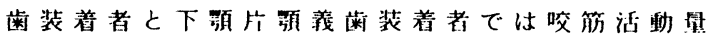
か小さくて咬合相時間か器かったととなる。 とれらの結果について，㐘根膜と粘膜の感賞受

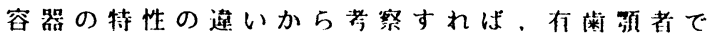
は閉口筋に対する歯根脱からの positive feedback が関与・.10してため門口動作か facilitate されたものと推祭される。また，上颣片顼茂歯 装着者では歯根膜からのpositive feedbackに 加えて，口蓝粘脱を完全に被璋した結果，乙の 部位の圧刺澈によって生しる開口反射機满い1１2， が抑制を受けたために咬筋活動量が增大したも

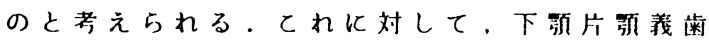
装着者では上弱料根膜からの感覚情報による閉 口筋へのpositive feedbackのほかにも，下顿 義菌㕅下粘膜感举加の開口反射成分の関与も 推测するととかできる。この開口反射成分につ

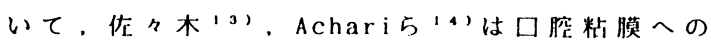
機械的刺激によって開口筋活動の抑制が浔めら

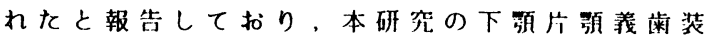
着者では床下粘膜への压刺激が開口及射成分の

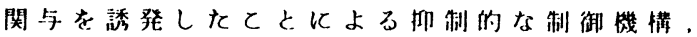
すなわち一㮔のnegative feedback効果かはた

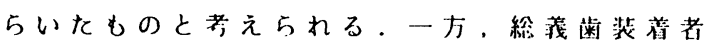
では開口動作へ切り変わるのに床下粘膜か時間

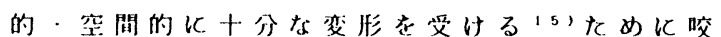
合相時間が延長したと、考えるととがでさる。

以上の結果から，朋影リスムの調節には末梢 性feedback情報は無視できないと考えられ，義 歯装着者に扰いてはとくに咬合相時閏のハラメ一 タが，咀噈運動機能評価飞有用であるととが示 咬された。

$$
v \text {.まとめ }
$$

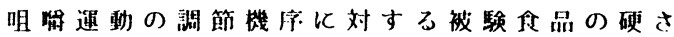

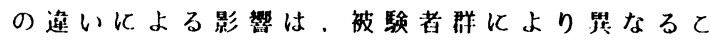
とが明らかとなった。すなわち，菌根䐵をすへ

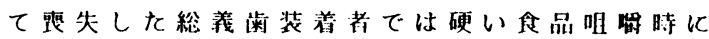
啁周期時間の延長を認め。乙れはとくに咬合 相時開の著明な延長による結果であるととが観

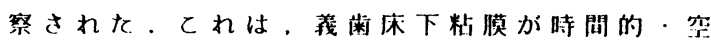
間的に十分な变形を受けるため咬合相時間か 延長したものと考えられた。一方，歯根䐵と義

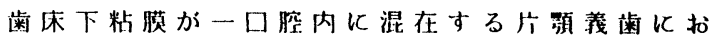

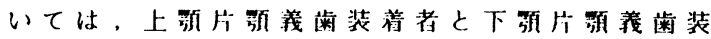
着者でその咀舸運動の調筑機序は明らかに異なっ ていた。すなわち。上确片颗義歯装着者は有料 确者と《西同しょらな結果を示したのに対し。

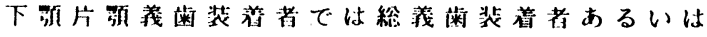
有蔽顼者のとちらにも似ていない特徽的な变動

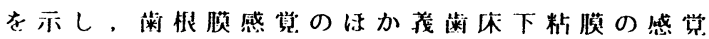
f eedbackによる影整が推测された。

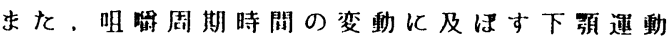

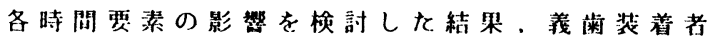

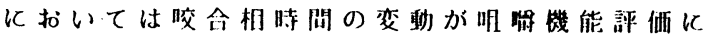
際して有用なバメ一タであるととが示唆され tc.

$$
\text { V1. 文献 }
$$

1) Lund, J.P. and Lamarre,Y. : The importance of positive feedback from periodontal pressoreceptors during voluntary isometric contraction of jaw closing muscles in man. $J$ Biol Buccale, 1 : $345 \sim 351,1973$.

2 ) Mushimoto,E. : The role in masseter muscle activities of functionally elicited periodontal afferents from abutment teeth under overdentures, J Oral Rehabil, 8: 441 455, 1981. 
3 ) Plesh.0.. Bishop, B. and McCall,W. : Effect of gum hardness on chewing pattern, Exp Neurol, 92 : 502 512, 1986.

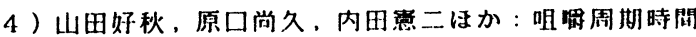
を変動させる要因，日本ME学会專門別研究会通回 第40回記念 弱口腔機能研究会抄録，6７，1992.

5 ) 鹿野洋一：総義歯装着者の咀程機能評価に関する臨 床的研究，一正常有蒾额者と総義菌装着者の咀啲運 動の比较について一，補䋚誌，34:318〜 332，1990.

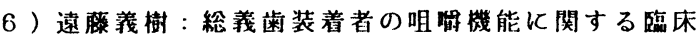
的研究。一床下粘膜の触・压感賞の違いが咀㖠筋

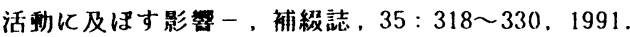

7 ）日塔晆雄：上, 下预Single Denture茈着者の咀謝 運動の調節機序に関する箭電图学的研究，補緅誌。 $36: 404 \sim 418,1992$.

8 ) Morimoto.T. Inoue.T. Nakamura.T. et al : Frequencydependent modulation of rhythmic human jaw movement. J Dent Res, 63: 1310 1314, 1984.

9) Thexton, A.J. . Hi iemae,K.M. and Crompton, A.W. Food consistency and bite size as regulators of jaw movement during feeding in the cat, J Neurophysiol, $44:$ 456 474, 1980.

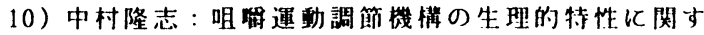
了研究、阪大菌学誌、32:36〜55, 1987.

11) Thexton,A.J. : Oral reflexes elicited by mechanical stimulation of palatal mucosa in the cat, Arch Oral Biol, 18:971 980, 1973.

12) Morimoto, T., Sakan, I.. Inoue,H. et al : Ef fects of palatal stimulation on muscle spindle activities of nasticatory muscles in a cat, edited by Kawanura,Y. and Dubner,R., Oral-facial sensory and motor functions, 63 71, Quintessence Publishing, Tokyo, 1981 .

13）佐々木啓一：開口反射機满に掩ける口腔粘膜受容

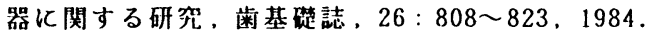

14) Achari,N.K. and Thexton, A.J. : A masseteric reflex elicited from the oral mucosa in man, Arch Oral Biol, 19: 299 302, 1974.

15) Brill.N. and Tryde,G. : Physiology of mandibular positions, edited by Kawamura,Y., Physiology of mastication, 199 237. Front Oral Physiol, 1: Karger, Basel, 1974. 